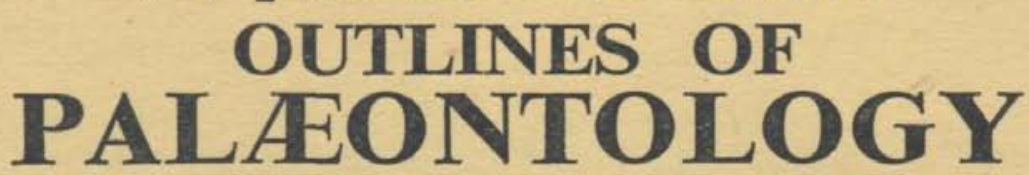

New (Third) Edition. By H.H.SWINNERTON, D.Sc., F.Z.S., F.G.S., Professor of Geology, University College, Nottingham. xii +394 pp., 368 figs. 30s. net

The new edition of this important book has been thoroughly revised and brought up to date. Publication is expected in July when copies will be obtainable through any bookseller.

Reprints expected in late summer

LAKE \& RASTALL'S

\title{
TEXT-BOOK OF GEOLOGY
}

Fifth Edition. Revised by R. H. RASTALL, Sc.D., F.G.S. viii +492 pp., 129 illus., 32 plates. 25s. net.

F. G. H. BLYTH'S

\section{GEOLOGY FOR ENGINEERS}

Second Edition. viii +330 pp., 141 figs., 16 plates. 21s. net.

\section{EDWARD ARNOLD \& CO. 41 MADDOX STREET, LONDON, W.1}

CECOND-HAND copies of January-February, March-April, MayJune, July-August, 1946, and May-June, 1940, Geological Magazines, urgently required. - STEPHEN AUSTIN \& SONS, LTD., 1 Fore Street, Hertford.

\section{The Geological Magazine}

Bound volumes are better than loose parts. Send your Geological Magazine to be bound in attractive green cloth covers, 9s. (postage 7d. extra); cloth cases only, 4s. (postage 3d. extra).

\section{STEPHEN AUSTIN \& SONS, LTD.} 1 FORE STREET, HERTFORD 